\title{
HYDROGEOCHEMISTRY FOR THE ASSESSMENT OF GROUNDWATER QUALITY OF SPRINGS ON ANDROS: AN ISLAND OF THE CYCLADES COMPLEX, GREECE
}

\author{
Filippidis F. ${ }^{1}$, Stamatis G. ${ }^{1}$, and Mantaloufa I. $^{2}$ \\ ${ }^{1}$ Agricultural University of Athens, Department of Natural Resources Management \& Agricultural \\ Engineering, St. Iera odos 75, 11855, Athens, Greece. \\ filippidis_filippos@aua.gr,filippidis_fil@hotmail.com and stamatis@aua.gr \\ ${ }^{2}$ Athens, St. Antinoros 16-18, 116 32, s_iwanna2@yahoo.com
}

\begin{abstract}
The paper presents the results of the physicochemical parameters of the springs of Andros which were studied to evaluate the chemistry of the major ions and solute acquisition processes, which control the chemical composition and the suitability of the quality of water for drinking use. Forty two samples were taken for physicochemical analysis almost at the end of the summer period, in September 2014. The Piper plot was used for the hydrogeochemical classification of groundwater which also indicated that the majority of groundwater samples belong to the $\mathrm{Ca}-\mathrm{Na}$ HCO3-Cl type. According to the Durov plot the majority of samples, can be positioned in field 2 in which a process of cation exchange is in progress. Also, the HCO3 / $(\mathrm{HCO} 3+\mathrm{SO} 4)$ ratio indicates a weathering process from carbonic acid. In general, the majority of samples can be characterized as potable.

Keywords: chemistry of major ions; solute processes; potable water.
\end{abstract}

\section{Пєрí $\eta \psi \eta$}

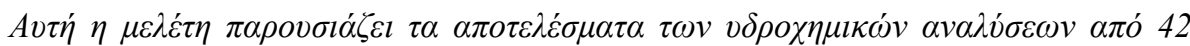

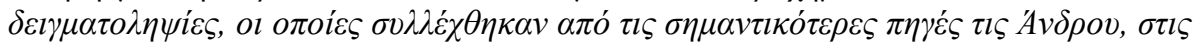

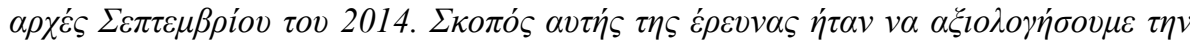

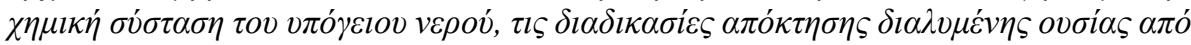

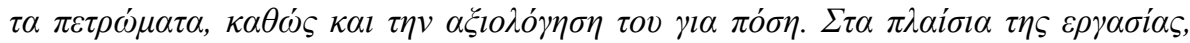

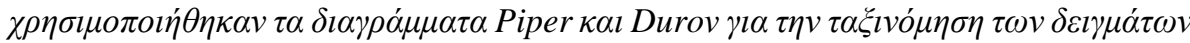

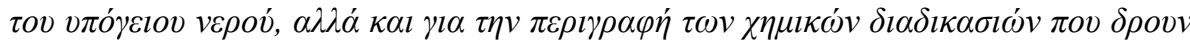

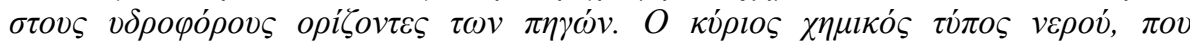

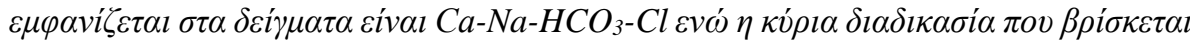

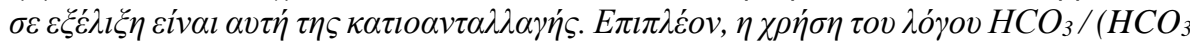

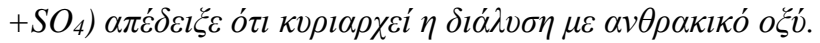

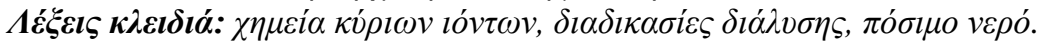

\section{Introduction}

Andros is an island, which is famous for its springs. This phenomenon is unique among the other islands of Cyclades. Andros has 24 Municipal Districts, of which, Andros (Hora), Batsi, Gaurio and Korthi consist the most important areas that have a need of water during the summer season. The majority of the Municipal Districts has an independent water supply system, which consists of 
boreholes, springs and limited wells. The same system applies for the individual houses and the groups of settlements. A characteristic example is a well, entitled Abyss, which supplies water to the town of Andros. In the study area, a lot of previous studies have described the hydrogeological conditions for each village (Gakis, 1979; Georgouli, 1983). The purpose of these studies was: a) the hydro-chemical analysis of springs, their comparison with the permissible limits of French (1954), American (1958), Greek (1968) and International (1958) standards for drinking use, and their presence into G. Waterlot plots, b) the classification of springs is based on the geologic and geomorphologic structure controlling their discharge and c) a presentation of a number of proposals for the improvement of the conditions regarding the water supply for each village. Furthermore, Giannoulopoulos and Lappas (2010) studied the hydrogeological conditions of Andros. Their studies are focused on the classification of groundwater according to Piper and Durov plots, the description of aquifers according to their hydraulic characteristics, and the assessment of the potential reserves for each aquifer system. In this study we report the results of the chemical analysis from 42 samples of springs, which were originated from all type of aquifers and which were collected in September 2014. The purpose of this paper is the description of the hydrogeochemical conditions and the identification of factors which govern the chemical composition of the groundwater of springs close to the end of the summer period. Furthermore, this paper focuses on the evaluation of the groundwater quality of springs for drinking and for general domestic use, because of their use from the inhabitants of island.

\section{Study Area}

\subsection{Location and morphology}

The area of interest in this paper is the island of Andros, which is located in the central part of the Aegean Sea and is the northest island of Cyclades, a complex of islands in Greece. The Greek Geographic Reference System is used for the definition of the study area which is Andros. The study area is bounded by $\mathrm{X}$ in the range from $560.000 \mathrm{~m}$ to $587.500 \mathrm{~m}$, and by $\mathrm{Y}$ in the range from 4.170.000 to 4.206.000 $\mathrm{m}$ (Fig.1). The island is characterized as an area of a total surface of $380 \mathrm{Km}^{2}$, a fact that places it as the second biggest island of Cyclades after Naxos. It also has an elongated form, which is characterized of an orientation NW-SE. Geomorphologically, the study area has a strong relief with deep ravines and large valleys, which transverse the island vertically at its longitudinal axis and divides it into four main mountain masses, which are from the North to the South: a) Saints Forty (720m), b) Petal or Kouvara (996m), c) Gerakona (720m) and d) Rachi or Prophet Ilias $(681 \mathrm{~m})$. The streams on the island of Andros are developed either side of the main elongated surface watershed with an orientation NW-SE, which matches to the axis of the great open fold across the island. The development of these hydrographic systems is taking place in parallel zones with a direction from NE to SW, while noteworthy is the fact that in the northeastern side the development of the hydrographic network predominates up to the third class (Strahler's classification) and in the southwestern side only the first class (Strahler's classification) is either predominant or even missing (Papanikolaou, 1978).

\subsection{Geology and Tectonic}

The geotectonic placement of Andros is located in the Attic-Cycladic Crystalline Belt and it is a major tectonostratigraphic unit of the Hellenides. Andros is divided in two tectonic units: a) the upper tectonic unit of Makrotantalon (upper Paleozoic) and b) the lower tectonic unit of the central - southern Andros (Papanikolaou, 1978). The geological formations which are observed on the island are described below (Fig.1). In the study area, the sedimentary rocks are represented by deposits, such as alluvial deposits (Al), screes (Q.sc), and recent or older sandstones (Qst or Qst $_{1}$ ). The upper tectonic unit of Makrotantalon consists of marbles (P.mr), mica schists with albite, chlorite, garnet and also phyllites, quartzites (P.sch) and chlorite-epidote-amphibolite schists to amphibolites (P.sch.ab). The lower tectonic unit of the central - southern Andros consists of the upper horizon of intermediate marbles $\left(\mathrm{mr}_{4}\right)$, cipolines and calcareous mica schists (sp,sch), middle 
horizon of intermediate marbles $\left(\mathrm{mr}_{3}\right)$, lower horizon of intermediate marbles $\left(\mathrm{mr}_{2}\right)$, alternations of thin-layered marble and mica schists $\left(\mathrm{mr}\right.$, sch), lower marbles $\left(\mathrm{mr}_{1}\right)$, mica schists, with albite, chlorite, garnet, glaucophane and some phyllittes and quartizites are also present (sch), chloriteepidote-amphibolite schists to amphibolites (sch. ab) and beds and lenses of marble or cipoline, which are located within the mica schists at various stratigraphic horizons (mr). Additionally, igneous Rocks are represented from dykes of acid igneous rocks, such as hornblende porphyrite, pegmatites and aplites $(\pi \gamma)$, gneissic granodiorite $(\gamma, \eta)$ and serpentinites to slightly serpentinised peridotites (o) (Papanikolaou, 1978). The structure of the island has been formed from three deformation phases and two fault phases. The first and second deformation phase gave only folds, foliation and cleavage. In addition, the first deformation phase consists of isoclinal folds with an axis orientation NE-SW, while the second deformation phase consists of folds with axis orientation E-W and ESE-WNW. The third deformation consists of folds with axis orientation NW-SE, N-S and faults. The fourth phase consists of faults and joints. The structure of the first deformation phase was deformed from the second phase without an important effect, while the third phase folded the two phases above. The result of the third deformation phase was the creation of a big asymmetric anticline fold which took place with an axis orientation NW-SE lengthwise of Andros (Papanikolaou, 1978). The faults are divided to four systems depending on their orientation. The systems are NWSE, E-W, NE-SW and B-N. The first group is also more preponderant in comparison to other systems. Furthermore, joints have same orientations and can be categorized to four systems as well as faults. The joint system, which prevails in schists is NW-SE, while the orientations NW-SE, EW, NE-SW and B-N prevail in cipolines and marbles (Papanikolaou, 1978).

\subsection{Hydrogeology-Aquifers}

In the study area, the geological formations can be divided into two main categories: a) permeable formations and b) semi-permeable formations. In particular, marbles and cipolines constitute the permeable formations. The category of the semi-permeable formations consists of alluvial deposits, screes, calcareous sandstones, schists, serpentinites and peridotites. The carbonate rocks are characterized from a secondary porosity e.g. cracks, joints, which facilitates the movement and storage of the groundwater. Also, because of intercalations of marbles and cipolines within the masses of schists create confined aquifers. In these confined aquifers, the provision of boreholes range from $5 \mathrm{~m}^{3} / \mathrm{h}$ to $40 \mathrm{~m}^{3} / \mathrm{h}$ for a depth of $80 \mathrm{~m}-130 \mathrm{~m}$, while the level of water is between $5 \mathrm{~m}$ and 60m (Giannoulopoulos and Lappas, 2010). The screes and calcareous sandstones can't form appreciable aquifers, but due to their limited thickness. The alluvial deposits could be characterized as a semi-permeable formation because of their low hydraulic conductivity. This parameter is related to the diversification of the extent, thickness and also the grain size (clay and sand) of the aquifers. These aquifers can be recharged directly from rainwater and screes or laterally from schists. The levels of groundwater respond to depths usually from 3 to $10 \mathrm{~m}$ and more than $30 \mathrm{~m}$. The provision of boreholes range from $10 \mathrm{~m}^{3} / \mathrm{h}$ to $40 \mathrm{~m}^{3} / \mathrm{h}$, while the provision of wells range from $5 \mathrm{~m}^{3} / \mathrm{h}$ to $20 \mathrm{~m}^{3} / \mathrm{h}$ (Giannoulopoulos and Lappas, 2010). All kinds of schists represent important aquifers because of their own fractures which are related to the anticline folds of the island. The anticline folds facilitate the movement of water, whose crest is submitted to higher tensional stresses and therefore it develops open tensile fractures, which may create better sites for groundwater development (Singhal and Gupta et al., 2010). As a result of the aforementioned development, many contact springs have been created between healthy bedrock of schists and carbonate rocks or mantle weathering of schists. In the study area, the choice of springs was based on their lithologic type, their tectonic structure and their discharge rate. The springs can be characterized as permanent (perennial springs) and their own discharge rate range from $0.10 \mathrm{~m}^{3} / \mathrm{h}$ to $7.4 \mathrm{~m}^{3} / \mathrm{h}$. 


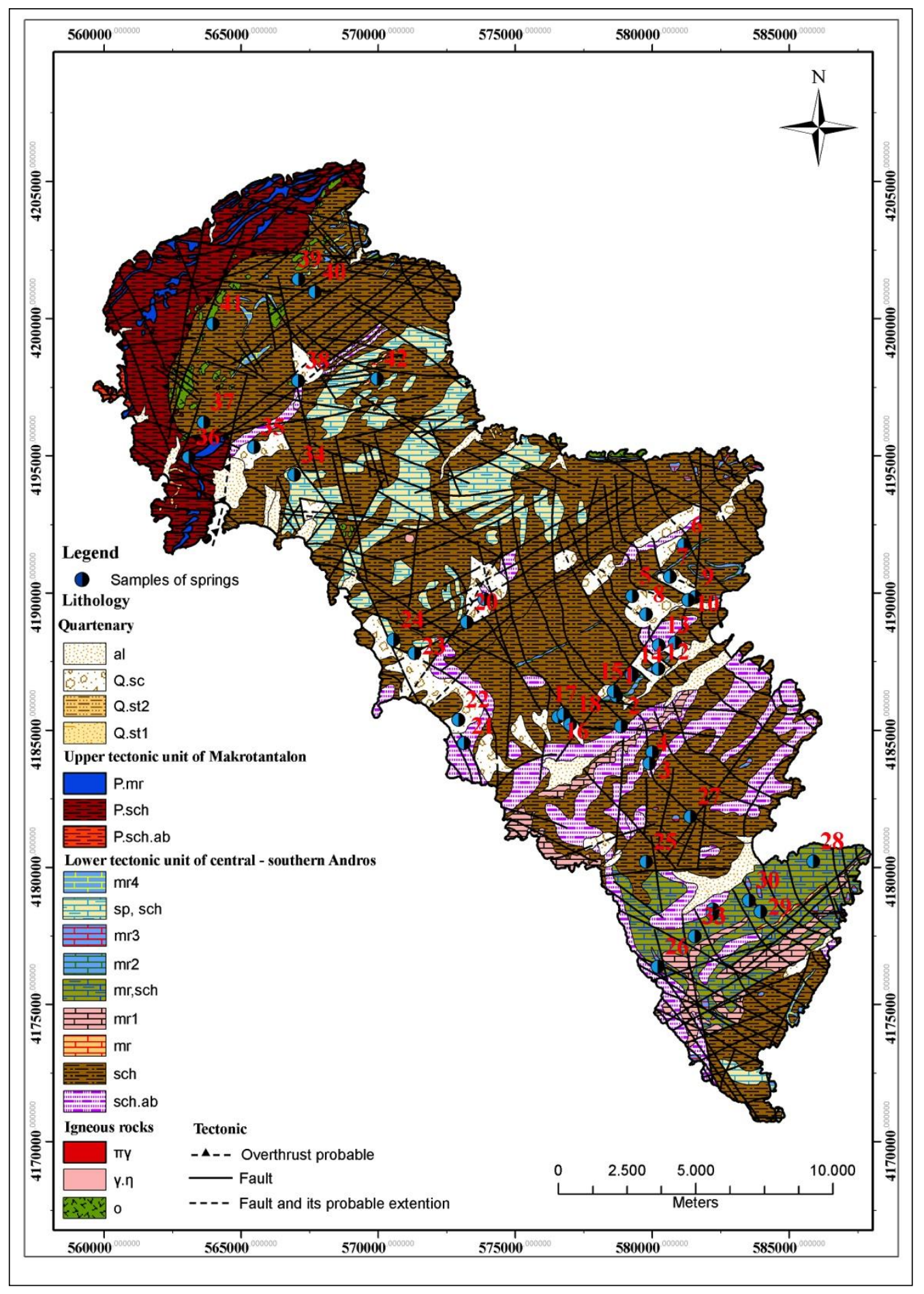

Figure 1 - Geological map of Andros with superposition of the sampling points (map according Papanikolaou, 1978).

These values of the discharge rate only concern a specific month of sampling in September 2014. The springs with discharge rates under $1 \mathrm{~m}^{3} / \mathrm{h}$ are represented from the following numbers: 2, 3, 6 , 
$7,10,11,13,14,19,21-27,31,35$, and $37-41$ while springs with a rate above $1 \mathrm{~m}^{3} / \mathrm{h}$ are represented from these numbers: 1, 4, 5, 8, 9, 12, 15-18, 20, 28-30, 32-34, 36 and 42 (Fig.1). The majority of springs are characterized as descending contact springs. There is also another category of springs which is related to the fault zones. Among all formations, the marbles and cipolines represent aquifers with more water supplies. In these formations and specifically into the fault zones, many springs with high discharge rate make their appearance.

\section{Materials and Methods}

A total of 42 groundwater samples of springs were collected from all types of geological formations in September 2014. The geographical location of all sampling sites was recorded using a hand-held global positioning system (GPS). At the same time, as the samples were taken, physical parameters such as electrical conductivity (E.C), temperature, salinity, $\mathrm{pH}$, redox potential (Eh) and dissolved oxygen $\left(\mathrm{O}_{2}\right)$, were recorded in situ, using portable equipment. The corresponding equipment contained a WTW LF 330/SET, a WTW PH 330i/SET and a WTW OXI96, respectively. All samples were collected in an $1 \mathrm{~L}$ polyethylene bottle for chemical analysis of major $\left(\mathrm{Ca}^{2+}, \mathrm{Mg}^{2+}, \mathrm{Na}^{+}, \mathrm{K}^{+}\right.$, $\left.\mathrm{HCO}_{3}{ }^{-}, \mathrm{Cl}^{-}, \mathrm{SO}_{4}{ }^{2-}, \mathrm{NO}_{3}{ }^{-}\right)$, and secondary ions $\left(\mathrm{NO}_{2}{ }^{-}, \mathrm{NH}_{4}{ }^{+}, \mathrm{PO}_{4}{ }^{-3}\right)$ and also for $\mathrm{SiO}_{2}$. Also, during the sampling and the transfer of the samples on the way to the laboratory of Geology and Mineralogy of the Agricultural University of Athens, the samples were stored into insulated boxes with ice packs, which offer constant and cool temperature. Chemical analysis of hardness, bicarbonate $\left(\mathrm{HCO}_{3}{ }^{-}\right)$, calcium $\left(\mathrm{Ca}^{2+}\right)$ and chloride $\left(\mathrm{Cl}^{-}\right)$were applied according to Hach's titration method. In addition, the ions of $\mathrm{SO}_{4}^{2-}, \mathrm{NO}_{3}{ }^{-}, \mathrm{NH}_{4}{ }^{+}, \mathrm{PO}^{-3}, \mathrm{NO}_{2}^{-}$and $\mathrm{SiO}_{2}$ were determined spectrophotometrically, using the spectrometer Hach DR-3000. Sodium $\left(\mathrm{Na}^{+}\right)$and potassium $\left(\mathrm{K}^{+}\right)$were determined with the flame photometry method, using the flame photometer INTECH/420.

\section{Results and Discussion}

\subsection{Quality of groundwater}

In order to achieve an easier description for the chemical composition of the spring waters, all samples were divided into three groups, depending on the lithologic type of their catchment area. Specifically, group 1 consists of the samples $23,24,26,28-34$ and 42 . These samples were collected from the following formations: a) cipolines with calcareous mica schist (sp,sch) and b) alternations of thin layered marble and mica schists (mr, sch). The second group consists of 25 samples (1-22, 25, 27 and 35) which were collected from the mica schists (sch) and the amphibolites (sch.ab). The third group consists of 6 samples (36-41) which were collected in the north section of the island. This group has some similarities with the other two, as all of them contain schists (predominant rock) and carbonate rocks. On the other hand, the third group is different to the others due to the existence of the serpentinites and the peridotites, which effect the chemical composition of groundwater. The results from the chemical analysis of the aforementioned three groups are presented in table 1 using three descriptive measures (minimum, maximum, average). Electrical conductivity (E.C) shows higher values in groups 1 and 3 in comparison to group 2 because of the increasing quantities of salts. The concentration levels for the total dissolved solids (TDS) for the majority of the samples of groundwater are under the limit of $1000 \mathrm{mg} / \mathrm{l}$ and they can be characterized as fresh water, apart from sample (40). Sample 40 belongs to the third group of table 1 , its value is $1014 \mathrm{mg} / \mathrm{l}$, so it could be considered as a slightly brackish water. The hardness of samples of group 1 ranges from hard to very hard, while those of group 2 range from a low to a very high hardness. The hardness of group 3 ranges from moderately hard to very hard. In general, the high concentrations of hardness are connected with the high concentrations of calcium and magnesium, but in the study area calcium is the element which shows greater concentrations than magnesium. The classification of hardness was realised according to Sawyer and McCarty (1967). Concerning the major cations, the predominant cation, for the majority of the groundwater samples, is calcium which is then followed by sodium and magnesium. This result is mainly observed in 
groups 1 and 2, but in group 3, the predominant cation is sodium which is then followed by calcium and magnesium (table 1), apart from two samples $(37,38)$, of which the predominant cation is calcium (Fig.1). In addition, there are some samples in which sodium is followed by calcium. These samples are $6,7,11,14,19$ and 35, which belong to group 2, while samples 24 and 28 belong to group 1. The ions of calcium and magnesium in groundwater are originated from the weathering of calcium carbonates (calcite), $\mathrm{Ca}-\mathrm{Mg}$ silicates (amphiboles) and epidote. Specifically in group 3, magnesium has a higher average value in comparison to groups 1 and 2, due to the appearance of serpentinites and slightly serpentinised peridotites, at the northern part of Andros. These rocks consist of olivine minerals, serpentine and talc (Papanikolaou, 1978). As a result, groundwater interacts with the above rocks and therefore it is enriched with magnesium.

Table 1 - Results of chemical analyses of groundwater samples from springs.

\begin{tabular}{|c|c|c|c|c|c|c|c|c|c|}
\hline & \multicolumn{3}{|c|}{ Group 1} & \multicolumn{3}{|c|}{ Group 2} & \multicolumn{3}{|c|}{ Group 3} \\
\hline & \multicolumn{3}{|c|}{ sp,sch and mr,sch } & \multicolumn{3}{|c|}{ sch and sch.ab } & \multicolumn{3}{|c|}{ P.sch, sch, and o } \\
\hline & \multicolumn{3}{|c|}{ (N=11samples) } & \multicolumn{3}{|c|}{ (N=25 samples) } & \multicolumn{3}{|c|}{ (N= 6 samples $)$} \\
\hline & Min & Max & Aver & Min & Max & Aver & Min & Max & Aver \\
\hline $\mathbf{T}\left({ }^{\circ} \mathrm{C}\right)$ & 15.9 & 21.9 & 18.4 & 11.9 & 21.5 & 17.5 & 14.8 & 22.7 & 19.5 \\
\hline pH & 7.09 & 7.66 & 7.41 & 6.7 & 8.01 & 7.4 & 7.34 & 7.95 & 7.57 \\
\hline Eh $(\mathrm{mV})$ & 372 & 443 & 423.7 & 369 & 472 & 436 & 379 & 430 & 404 \\
\hline DO (mg/l) & 8.5 & 9.8 & 9.0 & 8 & 9.7 & 8.9 & 8.2 & 9.3 & 8.8 \\
\hline $\mathrm{EC}(\mu \mathrm{S} / \mathrm{cm}) 25^{\circ} \mathrm{C}$ & 732 & 1121 & 859.5 & 273 & 1025 & 569 & 416 & 1303 & 967 \\
\hline Salinity & nd & 0.3 & 0.1 & nd & 0.3 & 0.1 & nd & 1.5 & 0.4 \\
\hline TDS (mg/l) & 535 & 775 & 639 & 183 & 741 & 418 & 308 & 1014 & 704 \\
\hline Hardess (mg/l) & 222 & 356 & 271.6 & 66 & 324 & 178.0 & 128 & 362 & 269.3 \\
\hline $\mathrm{Ca}^{2+}(\mathrm{mg} / \mathrm{l})$ & 72.8 & 116.8 & 86.8 & 14.4 & 99.2 & 53.6 & 36.8 & 86.4 & 71.1 \\
\hline $\mathrm{Mg}^{2+}(\mathrm{mg} / \mathrm{l})$ & 10 & 18.3 & 13.5 & 3.9 & 20.4 & 10.8 & 3.5 & 43.5 & 22.5 \\
\hline $\mathrm{Na}^{+}(\mathbf{m g} / \mathrm{l})$ & 58.7 & 130 & 80.1 & 24 & 96.4 & 50.4 & 34.4 & 180 & 106.7 \\
\hline $\mathrm{K}^{+}(\mathrm{mg} / \mathrm{l})$ & 0.6 & 8.5 & 1.7 & 0.3 & 1.8 & 1.1 & 0.8 & 1.7 & 1.3 \\
\hline $\mathrm{HCO}_{3}^{-}(\mathrm{mg} / \mathrm{l})$ & 201.3 & 366 & 263.4 & 61 & 317.2 & 178.6 & 128.1 & 323.3 & 256.2 \\
\hline $\mathrm{Cl}^{-}(\mathrm{mg} / \mathrm{l})$ & 106.4 & 241.1 & 140.2 & 39 & 170.2 & 86.8 & 60.3 & 294.3 & 176.1 \\
\hline $\mathrm{SO}_{4}^{2-}(\mathrm{mg} / \mathrm{l})$ & 17 & 45.6 & 29.8 & 3.2 & 43.7 & 17.7 & 20.8 & 89.7 & 44.0 \\
\hline $\mathrm{NO}_{3}^{-}(\mathrm{mg} / \mathrm{l})$ & 2.6 & 32.6 & 11.0 & 2.2 & 18.0 & 7.2 & 2.6 & 23.3 & 7.9 \\
\hline $\mathrm{NO}_{2}^{-}(\mathrm{mg} / \mathrm{l})$ & 0.01 & 0.02 & 0.02 & 0.01 & 0.02 & 0.02 & 0.01 & 0.04 & 0.02 \\
\hline $\mathrm{P}_{2} \mathrm{O}_{5}(\mathrm{mg} / \mathrm{l})$ & 0.06 & 0.40 & 0.32 & 0.19 & 0.43 & 0.33 & 0.16 & 0.44 & 0.28 \\
\hline NH4 (mg/l) & nd & 0.03 & 0.02 & nd & 0.09 & 0.03 & nd & 0.12 & 0.05 \\
\hline $\mathrm{SiO}_{2}(\mathrm{mg} / \mathrm{l})$ & 9.9 & 12.9 & 11.4 & 6.4 & 21.0 & 11.4 & 10.2 & 26.3 & 17.3 \\
\hline
\end{tabular}

Sodium is mainly originated from rain and the sea spray aerosol while potassium may comes from micas (muscovite). Concerning the major anions, the predominant anion for the majority of the groundwater samples, is bicarbonate and then followed by chloride and sulphate, except for some samples $(6,7,11,14,28,40$ and 41) where chloride prevails over bicarbonate. The bicarbonates are originated from the dissolution of carbonates and silicate minerals (Nandimandalam et al., 2010). The chlorides may mainly come from aerosol and rain. In the neighbor island of Tinos samples from rain were collected and their chemical analysis showed that $\mathrm{Cl}^{-}$had a range from $21.26 \mathrm{mg} / \mathrm{l}$ to 63.8 mg/l and it reached its highest value in April 1994 (Dazy et al., 1997). These concentrations suggest that the precipitations consist a source for a part of $\mathrm{Cl}^{-}$in the groundwater. Furthermore, chemical analysis of springs at Tinos showed that the concentrations of $\mathrm{Cl}^{-}$had very high values (e.g. Zodemeni spring: 91.8 - $173.7 \mathrm{mg} / \mathrm{l}$ and Ossia Xeni: 198 - $245 \mathrm{mg} / \mathrm{l})$ which is something that cannot be explained only as a result of rain, but the sea spray aerosol also seems to play an important role 
(Dazy et al., 1997). Sulfate ions have higher concentration levels in groups 1 and 3 in comparison to group 2 (table 1). The presence of the sulfate ions is mainly related to some surface effects, such as the drain tanks, the animal husbandry, and the transfer of the sea salts through aerosols. In addition, a proportion of $\mathrm{SO}_{4}{ }^{2-}$ could be related not only to the oxidation of the iron pyrite but also to the organic material of plant origin as well. Also the rain can offer small quantities of $\mathrm{SO}_{4}{ }^{2-}$. Chemical analyses of rain waters showed that the concentrations of sulfate ions range from $11 \mathrm{mg} / \mathrm{l}$ to 20.7 $\mathrm{mg} / \mathrm{l}$ at Tinos Island (Dazy et al., 1997). The concentration of the nitrate ion in the groundwater of springs is generally low in the study area. In particular, natural water only contains from $0.1 \mathrm{mg} / 1$ to 10mg/l (Davis and DeWiest, 1966). In the study area, only seven samples (samples: 2, 11, 23, 27 , 33,34 and 40) exceed the value of $10 \mathrm{mg} / \mathrm{l}$ and they represent a $16.7 \%$ of the total sampling. The presence of $\mathrm{NO}_{3}{ }^{-}$is related to some agricultural activities and animal husbandry. In particular, the average value for the silica of group 3 is higher than the respective value of groups 1 and 2 , which have the same average value (Table 1). This fact shows a weathering of silica minerals, which may be related to the serpentinites and the peridotites at the northern section of the island. Similar results for silica have been found at Karystia (south Evia) because of the metabasic and schist rocks (Stamatis et al., 2005).

\subsection{Hydrochemical phases (water types) and water mineralization processes}

From the chemical treatment of samples, seven types of water were distinguished: 1) $\mathrm{Ca}-\mathrm{Na}-\mathrm{HCO}_{3}-$ $\mathrm{Cl}$ (samples: 1-5, 8, 9, 12, 13, 15-18, 20-23, 25-27, 29-34, 37, 38, 42), 2) Ca- $\mathrm{Na}-\mathrm{Mg}-\mathrm{HCO}_{3}-\mathrm{Cl}$ (sample: 10), 3) Na-Ca- $\mathrm{HCO}_{3}-\mathrm{Cl}$ (samples: 19, 24, 35, 36), 4) Na-Ca-Mg-HCO $3-\mathrm{Cl}$ (sample: 39), 5) $\mathrm{Na}-\mathrm{Ca}-\mathrm{Cl}-\mathrm{HCO}_{3}$ (samples: 11, 14, 28, 41), 6) Na-Ca-Mg-Cl-HCO 3 (sample: 6, 40) and 7) Na-Mg$\mathrm{Cl}-\mathrm{HCO}_{3}$ (sample: 7) (Fig.2). The first and second type of water belongs to the category of the alkaline earth waters with a high rate of alkaline metals and bicarbonate anions. This category represents the majority of groundwater samples (71.4\%). This group is observed throughout Andros. The third and fourth type of water belongs to the category of the alkaline waters with bicarbonate anions. This group is observed in the northern part and in only two points of the central part and it represents the $11.9 \%$ of all samples. The other types of water $(5,6$, and 7$)$ belong to the category of the alkaline waters with chlorosulfate anions. This category represents the $16.7 \%$ of all samples of groundwater and is located in limited positions across Andros. Furthermore, the type of water Ca$\mathrm{Na}-\mathrm{HCO}_{3}-\mathrm{Cl}$ is the dominant type in groups 1 and 2, while group 3 represents all types of alkaline waters, which have been mentioned above. The springs with water types 1 and 2 show that the groundwater indicates a natural recharge, while the water types of 3, 4, 5, 6 and 7 show that the sea spray aerosol affects the quality of groundwater. In Durov plot, the groundwater samples are divided into four fields, where each field represents a hydrochemical trend (Fig.3). The samples with numbers $1,4,5,12,15,17,18$ and 31-34, which are located in field $1\left(\mathrm{Ca}^{2+}-\mathrm{HCO}_{3}^{-}\right)$, are fresh recharge waters. The samples are located in cipolines, mica schists with neighbouring appearance of marbles and mica schists. The samples, 2, 3, 8-10, 13, 16, 19, 20-27, 29, 30, 35, 36-39 and 42 are located in field $2\left(\mathrm{Mg}^{2+}-\mathrm{HCO}_{3}{ }^{-}\right)$, a fact that suggests that the cation exchange which takes place between water and aluminosilicate minerals, is still in progress. The samples with numbers 11 and 28 are located in field $8\left(\mathrm{Mg}^{2+}-\mathrm{Cl}^{-}\right)$and this fact suggests that the reverse ion exchange which takes place is still in progress. In field $9\left(\mathrm{Na}^{2+}-\mathrm{Cl}^{-}\right)$, which consists of samples $6,7,14,40$ and 41 , high concentrations of chloride $\left(\mathrm{Cl}^{-}\right)$and sodium $\left(\mathrm{Na}^{+}\right)$are observed. In addition, fields 8 and 9 suggest that these samples were affected from the sea spray aerosol. Finally, fields 1, 2, 8 and 9 represent $26.2 \%, 57.1 \%, 4.8 \%$ and $11.9 \%$ of all samples, respectively. 


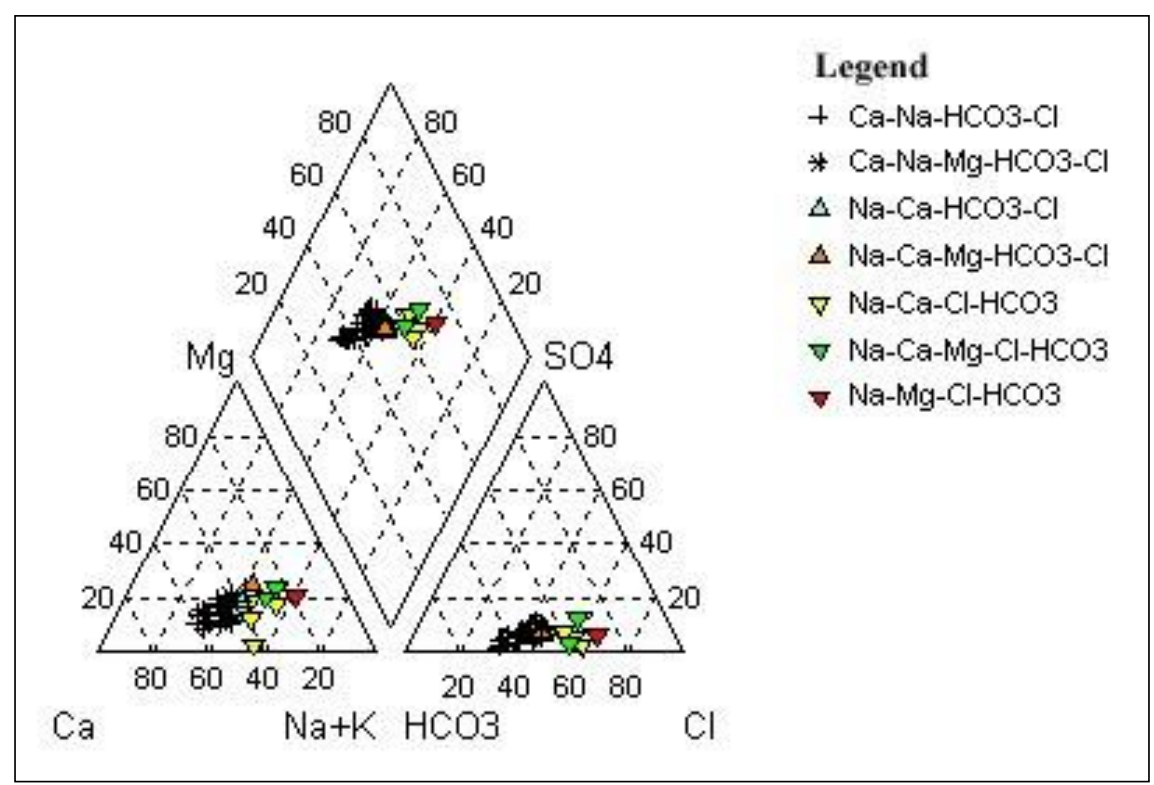

Figure 2 - Piper plot of chemical data in the study area.

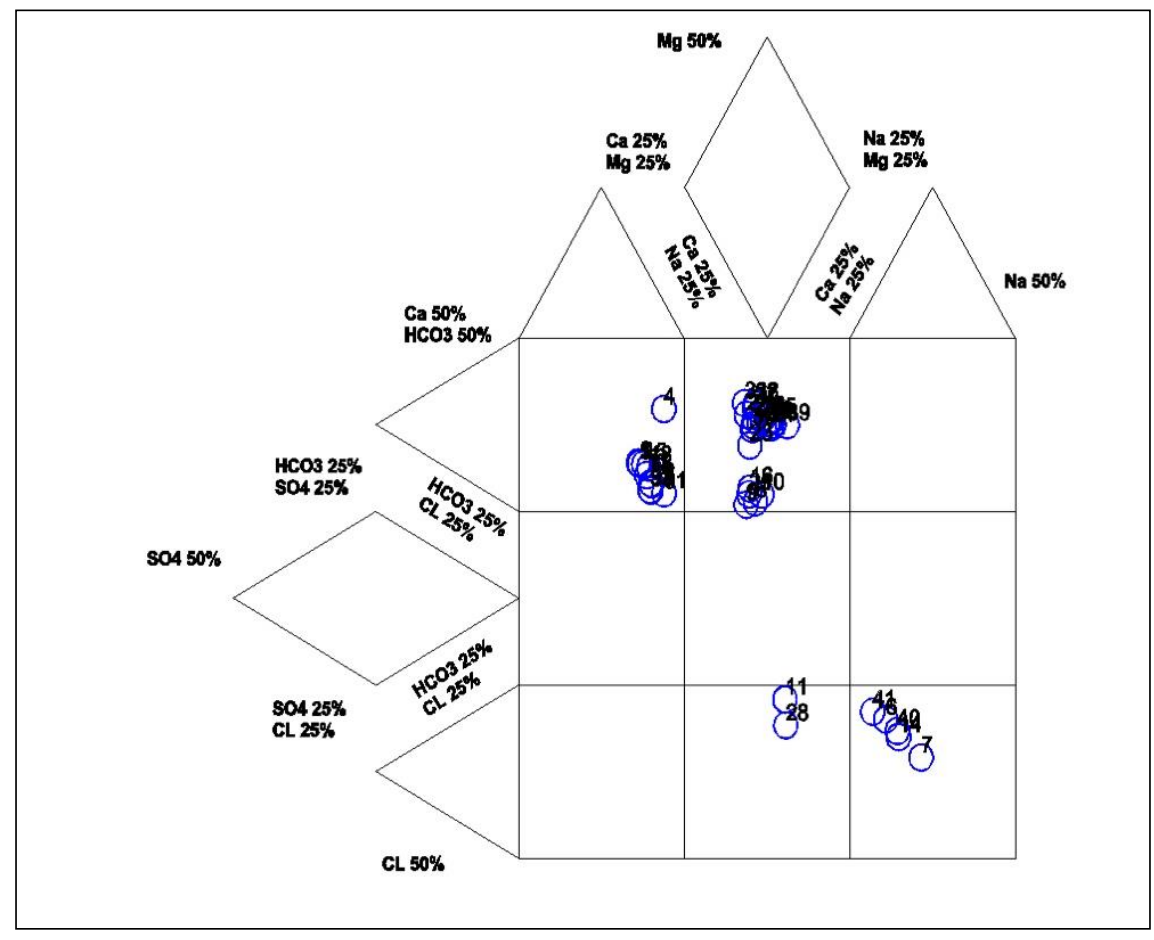

Figure 3 - Durov plot of chemical data in the study area.

The probable sources of these ions and water types in samples of groundwater suggest that a waterrock interaction takes place, such as the weathering of silicates and the dissolution of carbonates. The process of the weathering of silicates seems to be less prominent in relation to the weathering of carbonates, due to the fact that the samples had very low concentrations of magnesium in comparison to calcium. Drever (1997) has demonstrated that a ratio of $\mathrm{Mg}^{2+} /\left(\mathrm{Mg}^{2+}+\mathrm{Ca}^{2+}\right)$ in crystalline rocks greater than 0.5 may be due to the weathering of silicates. Among all the collected 
samples, only two of them had a value of 0.5 while all the other samples were below this value. Furthermore, when a ratio of $\mathrm{Mg}^{2+} / \mathrm{Ca}^{2+}$ has a value higher than 0.9 , this indicates a weathering of silicates. The same samples which are equal to 0.5 , according to the first ratio above, also have a value greater than 0.9 according to the second ratio. Specifically, the samples 7 and 40 have values 1.10 and 0.98 , respectively. This result shows that the silicate weathering is limited to a great extent. The dissolution of carbonate seems to be more prominent, because of the concentration levels of the bicarbonates which are high for the majority of the groundwater samples. Also, the relatively high ratio of $\mathrm{HCO}_{3}{ }^{-} /\left(\mathrm{HCO}_{3}{ }^{-}+\mathrm{SO}_{4}{ }^{2-}\right)$ in all of the groundwater samples is greater than 0.5 , which signifies a weathering from carbonic acid in these waters (Nandimandalam et al., 2010). The ratio $\mathrm{HCO}_{3} /$ $\left(\mathrm{HCO}_{3}+\mathrm{SO}_{4}\right)$ varies from 0.71 to 0.97 with an average value of 0.88 . In this study, it could be considered that, bicarbonates may derive from the dissolution of carbonate and silicate minerals by the carbonic acid. In addition, the first equation is equally important as the second one, because it explains the origin of sodium. Nevertheless, the ratio $\mathrm{Na}^{+} /\left(\mathrm{Na}^{+}+\mathrm{Cl}^{-}\right)$varies from 0.41 to 0.50 with an average value of 0.47 and it doesn't exceed the value of 0.5 , which indicates an incongruent dissolution of albite (Adomako, 2010). According to the result above, it is possible that sodium is mainly originated from sea spray aerosol. Furthermore, the ratio $\left(\mathrm{Ca}^{2+}+\mathrm{Mg}^{2+}\right) /\left(\mathrm{Na}^{+}+\mathrm{K}^{+}\right)$ranges from 0.65 to 2.40 with an average value of 1.57 . The observed average ratio and the relatively high contribution of alkalies $(40 \%)$ toward the total cations suggest that the combined reactions involving carbonate and silicate weathering controlled the solute acquisition process.

\subsection{Suitability for drinking and general domestic use}

The concentrations of hydrochemical parameters of groundwater of springs on Andros and their comparison to the prescribed specification of the European Directive (98/83) will be described below. The European Directive (98/83) doesn't give permissible limits for phosphorus pentoxide. For this reason, the 80/778EEC Directive was used. In the study area, the samples do not exceed the limits, which are suggested by the European Directive $98 / 83$ for the chemical parameter of $\mathrm{pH}(\geq 6.5$ and $\leq 9.5$ ). Conductivity has a permissible limit of $2500 \mu \mathrm{S} / \mathrm{cm}$ at $20^{\circ} \mathrm{C}$, which is equivalent to $\approx$ $2750 \mu \mathrm{S} / \mathrm{cm}$ at $25^{\circ} \mathrm{C}$, and it could be considered that E.C increases approximately $2 \%$ for each Celsius degree (Kallergis, 2000). The samples do not exceed the above limits of electrical conductivity (E.C). The concentrations of dissolved oxygen are very good and are over $5 \mathrm{mg} / \mathrm{l}$. None of the groundwater samples exceed the permissible limit for sodium, according to the European Directive 98/83, which is $200 \mathrm{mg} / \mathrm{l}$. According to the European Directive 98/83, chloride has a permissible limit of $250 \mathrm{mg} / \mathrm{l}$. None of the samples exceed this limit apart from only one sample (40) and therefore, sample 40 can't be considered as potable. Furthermore, the European Directive $98 / 83$ sets the following permissible limits $50 \mathrm{mg} / \mathrm{l}, 250 \mathrm{mg} / \mathrm{l}, 0.5 \mathrm{mg} / \mathrm{l}, 0.5 \mathrm{mg} / \mathrm{l}$ and $5 \mathrm{mg} / \mathrm{l}$ for nitrate, sulphate, nitrite, ammonium and phosphorous pentoxide, respectively. In this study, none of the groundwater samples exceed the above limits. Generally, the quality of groundwater concerning the above parameters renders the water potable.

\section{Conclusions}

Hydrochemistry reveals that the cation abundance follows this order $\mathrm{Ca}^{2+}>\mathrm{Na}^{+}>\mathrm{Mg}^{2+}>\mathrm{K}^{+}$except for some groundwater samples where $\mathrm{Na}^{+}$prevails over $\mathrm{Ca}^{2+}$ and just one case where the order changes to $\mathrm{Mg}^{2+}>\mathrm{Na}^{+}>\mathrm{Ca}^{2+}$. The order of the anion abundance is $\mathrm{HCO}_{3}{ }^{-}>\mathrm{Cl}^{-}>\mathrm{SO}_{4}{ }^{2-}$ except for some samples where $\mathrm{Cl}^{-}$prevails over $\mathrm{HCO}_{3}{ }^{-}$. The majority of groundwater samples (69\%) is also represented by the $\mathrm{Ca}-\mathrm{Na}-\mathrm{HCO}_{3}-\mathrm{Cl}$ type. According to the concentrations of TDS, the samples can be characterized as fresh waters, apart from one case (40), which is slightly brackish. The hardness of samples range from moderately hard to hard, with a limited number of samples which have low and very high hardness. The sources of $\mathrm{NaCl}$ are originated from rain and sea spray aerosol. At the northern section of the island, the concentrations of silica and magnesium increase from peridotites and serpentinites. The combination of ratios $\mathrm{Mg}^{2+} /\left(\mathrm{Mg}^{2+}+\mathrm{Ca}^{2+}\right)$ and $\mathrm{Mg}^{2+} / \mathrm{Ca}^{2+}$ indicates the less prominent weathering of the silicates, while the ratio of $\mathrm{HCO}_{3}{ }^{-} /\left(\mathrm{HCO}_{3}{ }^{-}+\mathrm{SO}_{4}{ }^{2-}\right)$ signifies a weathering from carbonic acid in these waters. Also, the ratio $\mathrm{Na}^{+} /\left(\mathrm{Na}^{+}+\mathrm{Cl}^{-}\right)$doesn't indicate an incongruent 
dissolution of albite, but it indicates that sodium mainly comes from the sea spray aerosols. According to Durov plot, the samples are distinguished into two groups of groundwaters. The first group showed that these groundwaters are characterized as fresh recharge waters which incur a phenomenon of cation exchange $(\mathrm{Ca}-\mathrm{HCO} 3 \rightarrow \mathrm{Mg}-\mathrm{HCO} 3)$. The second group of samples is affected from the sea aerosols and it incurs a phenomenon of reverse ion exchange. Finally, the groundwater of springs can be considered as suitable for drinking, according to the major ions and the other elements, which are associated with the agricultural activities, the drain cesspools and the animal husbandry.

\section{References}

Adomako, D., Osae, S., Akiti, T., Faye, S. and Maloszewski, P., 2011. Geochemical and isotopic studies of groundwater conditions in the Densu River Basin of Ghana, Environmental Earth Sciences, 62(5), 1071-1084.

Davis, S. and DeWiest, R., 1966. Hydrogeology, John Wiley \& Sons, Inc, New York, London, Sydney, $463 \mathrm{pp}$.

Dazy, J., Drogue, C., Charmanidis, Ph. and Darlet., Ch., 1999. The influence of marine inflows on the chemical composition of groundwater in small islands: the example of the Cyclades (Greece), Environmental Geology, 31, 133-141.

Drever, J.I., 1997. The geochemistry of natural waters surface and groundwater environments, $3^{r d}$ edn. Prentice Hall, Upper Saddle River, NJ, 436 pp.

Gakis, I., 1979. Hydrogeological recognition of the Stenies community on the island of Andros, Institute of Geology and Mineral Exploration, Athens, 8 pp.

Georgouli, A., 1983. Hydrogeological recognition of the village Gaurio (Ag. Petros) and the community of Palaiopolis on the island of Andros, Institute of Geology and Mineral Exploration, Athens, 13 pp.

Giannoulopoulos, P. and Lappas, J., 2010. Operational programme competitiveness - project: Recording and evaluation of the hydrogeological character of groundwater and aquifer systems of the country - Subproject 7: Assessment of the water resources of the Aegean. Quality controls and exploitation proposals (hydrological section 14), Institute of Geology and Mineral Exploration, Athens, $727 \mathrm{pp}$.

Kallergis, G., 2000. Applied environmental hydrogeology, Technical Chamber of Greece, Athens, $345 \mathrm{pp}$.

Nandimandalam, J.R., Shukla, U.K. and Prahlad, R., 2011. Hydrogeochemistry for the assessment of groundwater quality in Varanasi: a fast - urbanizing center in Uttar Predesh, India, Environmental Monitoring and Assessment, 173(1-4), 279-300.

Papanikolaou, D., 1978. Ph.D. study: Geological research at Andros Island, Athens, 221 pp.

Papanikolaou, D., 1978. Geological map of Greece in scale 50.000, Andros Sheet. Institute of Geology and Mineral Exploration, Athens.

Singhal, B. and Gupta, R., 2010. Applied Hydrogeology of fractured Rocks, Springer Science + Business Media B.V., Dordrecht, Heidelberg, London, New York, 408 pp.

Sawyer, C.N. and McCarty, P.L., 1967. Chemistry for sanitary engineers, 2nd ed., McGraw-Hill, New York, 518 pp.

Stamatis, G., Vitoriou, A. and Zaggana, E., 2005. Hydrogeological conditions and groundwater quality of Karystia crystalline-schist masses (N.Euboea), Proc. of the $7^{\text {th }}$ Hellenic Hydrological conference, Athens, 463-470. 